\title{
Przestrzeń wzruszonych. Edukacja liberalna a sfera publiczna (głos reanimacyjny)
}

\section{Kondycyjne pytania}

W wywodzącym się z artes liberales kształceniu ogólnym zawsze ostatecznie chodzi o wolność. Ażeby nie pogodzić się z senną egzystencją zakładnika socjalizacji albo niewolnika dominujących w otoczeniu tendencji, trzeba zbudować (w) sobie strefę suwerenności, a to dokonuje się zwykle wtedy, gdy chcemy i potrafimy stawiać niebanalne pytania. Liberal education to styl wychowania, w którym podstawową troską jest konfrontacja z najważniejszymi pytaniami i najciekawszymi próbami odpowiedzi na nie, jakie ludzie zdołali sformułować. Co mogę wiedzieć? Co powinienem czynić? Czego mogę się spodziewać? Czym jest człowiek? - jak uczył myśleć Immanuel Kant; albo w wersji Paula Gauguina: Skąd przyszliśmy? Kim jesteśmy? Dokąd idziemy? - oto fundament edukacji, która nie chce zgodzić się na ograbienie życia z jego ludzkiego pierwiastka, na okaleczenie człowieka i skazanie go na (prze)trwanie w postaci mentalnego kadłubka.

Przez pryzmat pytania Kim jest człowiek? widział sens tradycji liberal education jeden z jej najlepszych znawców, Allan Bloom: „Edukacja liberalna polega właśnie na tym, by pomóc studentom w postawieniu sobie tego pytania, w uświadomieniu sobie, że odpowiedź nie jest ani oczywista, ani

* Dr hab. Krzysztof Maliszewski jest adiunktem w Zakładzie Podstaw Pedagogiki i Historii Wychowania w Instytucie Pedagogiki Uniwersytetu Śląskiego w Katowicach. 
jednoznacznie nieosiągalna, że nie można nazwać poważnym życia, w którym pytanie to stale nie rozbrzmiewa" . Amerykański myśliciel zwrócił również uwagę na transformacyjny i rewizyjny charakter kształcenia ogólnego: „Edukacja liberalna jest autentyczna tylko wtedy, kiedy radykalnie zmienia całe życie studenta, kiedy wpływa na jego działania, upodobania i wybory, kiedy wszystkie jego dotychczasowe lojalności podlegają powtórnemu rozpatrzeniu i ocenie"'. Ten aspekt formacyjny ma w edukacji liberalnej szczególne znaczenie, jako że oczekiwania, nastawienia, horyzonty, potrzeby mają tu - inaczej niż w usługowo pojmowanym instruktażu - ulec sublimacji, przewartościowaniu, przesterowaniu, pogłębieniu, korekcie, a przynajmniej krytycznemu sprawdzeniu. Brak znaczących odkryć co do możliwości własnego człowieczeństwa i realizacja najbliższego dostępnego scenariusza społecznego to porażka edukacji liberalnej. „Rzeczywistym problemem jest niemrawość myślowa, charakteryzująca tych obywateli demokratycznego społeczeństwa, którzy przejawiają skłonność do kroczenia przez życie bez podejmowania namysłu nad możliwymi alternatywami oraz przesłankami własnych przekonań" ${ }^{3}$ - pisała Martha Nussbaum, dla której - zgodnie z klasyczną koncepcją - kształcenie ogólne polega na podejmowaniu krytycznego namysłu nad życiem, wyzwalającego umysł z krępujących go przyzwyczajeń i kształtującego wrażliwych i czujnych obywateli świata.

Uniwersytety stanowią nie jedyną wprawdzie, ale uprzywilejowaną przestrzeń tak pojmowanej pedagogicznej troski o czlowieczeństwo i demokrację. Dotyczy to także średnich szkół ogólnokształcących, a w pewnej mierze całej edukacji. Ustrój demokratyczny nie ma zdolności odtwarzania

${ }^{1}$ A. Bloom, Umyst zamknięty. O tym, jak amerykańskie szkolnictwo wyższe zawiodło demokrację i zubożyło dusze dzisiejszych studentów, Poznań 1997, s. 21. Chociaż A. Bloom w Umyśle zamkniętym niektóre sprawy nadmiernie upraszcza - irytująco całe pola badań sprowadza do ,intencjonalnego" działania przeciw komuś lub czemuś, jednoczynnikowo wyjaśnia złożone zjawiska (np. trwanie idei porządku wszechrzeczy), płytko i niesprawiedliwie kojarzy niektóre nurty teoretyczne i książki, wypowiada trochę głupstw o muzyce rockowej - to jednak jest to fascynująca i w wielu miejscach mądra książka - jedno z najlepszych wprowadzeń do zagadnienia edukacji liberalnej i misji uniwersytetów, jakie znam.

2 Tamże, s. 443.

${ }^{3}$ M. Nussbaum, W trosce o człowieczeństwo. Klasyczna obrona reformy kształcenia ogólnego, Wrocław 2008, s. 32. Książka ta - pomyślana poniekąd jako polemika z Umystem zamkniętym Blooma - jest bardzo ciekawym przywołaniem ważnej dla edukacji liberalnej sokratejsko-stoickiej tradycji myślenia wątpiącego, choć jej Autorka naraża się też na zarzuty, m.in. nazbyt stereotypowego i redukcyjnego pojmowania autorytetu. Por. L. Witkowski, Historie autorytetu wobec kultury i edukacji, Kraków 2011, s. 259-273. 
warunków własnego istnienia. Prawa człowieka, ponadpartykularne wartości, zasoby tradycji, refleksyjność etc. - to wszystko, bez czego demokracja zamienia się w legitymizowany głosowaniem totalitaryzm albo despotyczną kumulację absurdów i głupstw, ulega zazwyczaj w egalitarnych procedurach spłaszczeniu bądź zapomnieniu i musi być odtwarzane i rozwijane na mocy autorytetu. W tym sensie szkoły, a zwłaszcza akademie, stanowią wykrojony ze zwyczajnego życia społecznego areał pracy odbudowywania intelektualnego i etycznego potencjału, dzięki któremu demokracja może właściwie funkcjonować. Zwrócił na to uwagę Allan Bloom, akcentując za Alexisem de Tocquevillem konieczność istnienia instancji obrony przed wszechwładnością opinii publicznej:

Wyższe uczelnie są zatem osnową liberalnej demokracji, jej fundamentem, rezerwuarem zasad, które ją ożywiają, oraz niewysychającym źródłem wychowania i wiedzy napędzającej maszynerię ustroju. [...] Uniwersytet broni tego społeczeństwa nie dlatego, że podziela jego interesy, lecz dlatego, że równowaga sił w takim społeczeństwie wymaga, aby większość potrzebowała, szanowała, i stąd - chroniła wolność myślenia ${ }^{4}$.

\section{Epitafium}

Wszystko wskazuje na to, że tradycja liberal education - przynajmniej w polskiej rzeczywistości (ale nie tylko!) - została zaprzepaszczona. Jeśli gdzieniegdzie daje jeszcze znaki życia, to tylko dzięki indywidualnym wysiłkom i wbrew ramom instytucjonalnym oświaty oraz klimatowi społecznomedialno-politycznemu. Niemal nikt w naszej cynicznej i posttraumatycznej epoce duchowego wyczerpania nie traktuje na serio czasu kształcenia jako okazji do konfrontacji z kondycyjnymi pytaniami i do rozeznawania się w możliwościach egzystencji. Nie tylko decydenci, ale też ogromna część uczestników edukacji nie ma świadomości, że wychowanie nie może mieć charakteru usługowego i konsumpcyjnego, ponieważ polega nie na bieżącym zaspokajaniu, lecz na osadzonym w tradycji przeksztatcaniu ludzkich potrzeb. Powszechnym narzekaniom na słabości sfery publicznej, na brak albo katastrofalny poziom debat społecznych nie towarzyszy myśl, że mądre rozwiązania i głębokie refleksje nie biorą się znikąd i że muszą istnieć wolne

${ }^{4}$ A. Bloom, dz. cyt., s. 308. 
od nacisków doraźnej polityki i ekonomii przestrzenie namysłu, a także szerokie kręgi inteligentnych i przygotowanych jego twórców i odbiorców.

Moja teza jest taka: edukacja liberalna, dająca uczniom szansę na niezależność myślenia i duchową wolność, a demokracji na rekonstrukcję warunków jej niepatologicznego istnienia, znajduje się w stanie śmierci klinicznej. W praktyce kształcenia - poza pustymi deklaracjami okolicznościowymi i wciąż funkcjonującymi (na szczęście!) wyspami oporu - jest niemal nieobecna. Została zniszczona przez zapomnienie własnych źródeł i przez brak wyczulenia na perwersyjne efekty utylitaryzmu - uzawodowienia i biurokratyzacji szkolnictwa. Nie można jednak - jestem przekonany - przejść nad tym do porządku. Ranga sprawy jest tak duża, że trzeba wbrew chórowi „realistów” pilnie reanimować liberal education, aktualizując jej emancypacyjny potencjał.

\section{Zniszczenie dyspozycji do zapytywania}

Uczniowie przychodzą do szkół, a studenci na uniwersytet ze swoimi naturalnymi, ukształtowanymi przez najbliższe otoczenie i przekazy medialne nastawieniami. Wprowadzenie w ważkie egzystencjalne problemy i zaawansowane treści kulturowe nie pojawia się samo z siebie, nie wynika ot tak z zaabsorbowania codziennością ani ze sklejenia ze stereotypami i przyzwyczajeniami lokalnego środowiska, ale stanowi efekt udanej interwencji pedagogicznej. To szkoła i uniwersytet ma być świa tem, który człowiekowi otwiera oczy na w uśpieniu doraźnością nieprzeczuwane bogactwo kultury i na możliwości wielowymiarowego tworzenia własnego życia. Kłopoty zaczynają się wtedy, kiedy decydenci oraz podmioty edukacji zapominają o tym zadaniu i zamiast troski o centralne usytuowanie najważniejszych ludzkich pytań, zaczynają postrzegać kształcenie wedle wzorców handlowych, tzn. instytucje edukacyjne traktować jak punkty usługowe reagujące na popyt, a uczniów i studentów jak klientów. Taka logika musi zmarginalizować, a ostatecznie usunąć z pola widzenia troskę o człowieczeństwo, a więc sens liberal education, jako że właśnie ta troska nie jest składnikiem zwyczajnego zapotrzebowania społecznego. Możemy, rzecz jasna, próbować wyobrazić sobie rzeczywistość bez niej, ale nie da się tego zrobić - tak uważam - w dobrej wierze, ponieważ świat bez takiej troski nie może w znanym nam sensie zostać uznany za ludzki, a tym samym wart zaangażowania i ochrony.

Filozof Tadeusz Gadacz napisał kiedyś: 
Uznajemy za oczywistość, że musimy rozwijać nowe technologie i zajmować się nowymi materiałami po to, by móc uzyskiwać coraz to lepsze telefony komórkowe. Ale czy ktoś postawił sobie pytanie, czy my potrzebujemy telefonów komórkowych nowej generacji? Do czego ich potrzebujemy? Czy to jest konieczne? Takie pytania właściwie dziś nie padają, a mnie się wydaje, że są to pytania ważne. Być może nie potrzebujemy nowych technologii, ale... zachwytu literaturą. Problem tkwi zatem w dyskusji nad sprawami oczywistymi, które przyjmowane są bezkrytycznie jak niepodważalne kanony ${ }^{5}$.

Oczywiście absurdalne byłoby czytanie tej wypowiedzi jako głosu usiłującego powstrzymać rozwój technologiczny, bo nie humanistyczna utopia jest jej intencją, tylko zwrócenie uwagi na uwiąd dyspozycji do problematyzowania rzeczywistości oraz na zasłonięte, niedoceniane wymiary egzystencji. Możemy rzecz sformułować podobnie w odniesieniu do kształcenia. Przyjęliśmy za niepodlegające dyskusji, że szkoła i uniwersytet mają reagować na zapotrzebowanie społeczne i przygotowywać do rynku pracy. Niemal nikt już nie pyta, czy aby na pewno? Czy to wpisuje się w tradycję? Czy nie przyniesie perwersyjnych, odwróconych efektów? Czy projektuje ludzki świat? A może potrzebujemy czegoś innego?

Komercyjny model edukacji produkuje ciszę niepomyślanych pytań. Nie ma powodu, aby je stawiać. Konsument - pokazywał to Zygmunt Bauman - nie kieruje się ani zasadą przyjemności, ani zasadą rzeczywistości, tylko „zasadą wygody” - nie zamierza wysilać się, nawet dla przyjemności 6 . $\mathrm{W}$ innym miejscu Bauman uczulał na fakt, że ofensywa rynkowa niszczy „sztukę socjalności” - zamiast twórczego podejścia do relacji interpersonalnych, ludzie wolą zachowywać się zgodnie z instrukcją i nie wychylać poza aktualnie modny wzorzec postępowania, bo to umożliwia zrzucenie z siebie odpowiedzialności ${ }^{7}$. Traktowanie edukacji jak usługi, a uczniów jak klientów uderza w etyczne filary kształcenia: wartość wysiłku i dyspozycję do brania na siebie odpowiedzialności. To nie jest przypadek, że im więcej rezonuje się o innowacyjności i samodzielności w przestrzeni edukacji, a de facto usługowo organizuje nauczanie, tym powszechniej mamy do czynienia z ludźmi roszczeniowymi, biernymi, bezmyślnie uległymi wobec regulaminów i procedur, i niezdolnymi do etycznego, a nie tylko administracyjnego, podjęcia odpowiedzialności za własne działanie. Wbrew mitowi twórczej

5 T. Gadacz, Bankructwo czy ,tylko” kryzys?, „Znak” 3 (2010), s. 96.

${ }^{6}$ Por. Z. Bauman, Prawodawcy i thumacze, Warszawa 1998, s. 250.

${ }^{7}$ Por. tenże, Razem, osobno, Kraków 2003, s. 181. 
szkoły współczesny konsumpcyjny habitus nie potrzebuje wcale myślących i kreatywnych jednostek. Dziś potrzebni są ludzie sprawni, rzutcy i bezkrytyczni. Tylko ktoś, kto nie podejmuje refleksji nad sensem działania i nie zdaje sobie sprawy z imponderabiliów i wielowymiarowości życia i kultury, jest w stanie utrzymać świadomość na konsumpcji. Edukacja liberalna, gdyby nie została zneutralizowana marginalizacją oraz przeniesieniem do retorycznego wymiaru czczych deklaracji, niechybnie uwalniałaby myślenie z kolein doraźności.

Kryzys bezinteresowności, w znaczeniu nieuznawania za istotne niczego, czego nie daje się pomyśleć jako bezpośredniej drogi do ekonomicznego czy prestiżowego sukcesu, a właściwie - tak należałoby to ująć - kryzys interesowności egzystencjalnej, w polu której pulsuje niedosyt znaczenia oraz zaciekawienie tajemniczością i złożonością życia (np. wedle formuły Sándora Máraia: „Niemożliwe, żeby chodziło tylko o to”8), sprawia, że karmiąca się pytaniami liberal education nie znajduje żyznej dla siebie gleby. Instytucje oświatowe w dużej mierze przestały być miejscem kształcenia, a stały się jedynie środkiem budowy CV w nieproblematycznym (już prawie dla nikogo) rynkowym horyzoncie. Nawet eksponowana dziś idea całożyciowego uczenia się ma niewiele wspólnego z tradycją pedagogicznego uwalniania umysłu z krępujących go środowiskowych przesłon i więzów. W ostatnim czasie - ilustracyjnie przywołajmy dwie lektury - najpierw Lech Witkowski zdemaskował mit „społeczeństwa wiedzy” oraz pokazał, jak pozornie wartościowe jest przejście od instytucjonalnej edukacji do rozmaitych form biograficznego uczenia się, skoro najczęściej sprowadza się do konsumowania instruktażu i banalnej papki informacji ${ }^{9}$, a następnie Zbyszko Melosik zdarł maskę z hasła lifelong learning, zauważając, że ma ono dziś charakter negatywny - nie odwołuje się do idei i praktyki wzbogacania egzystencji człowieka, lecz do zjawiska inflacji kwalifikacji zawodowych bądź współczesnego lęku, by „nie wypaść z gry”, a zatem wzmaga tylko socjalną niepewność jednostki i jej adaptacyjne odruchy ${ }^{10}$. Nie ma edukacji liberalnej bez pytań, pragnień, wątpliwości, nadziei, przeżyć, których można - z łatwością - sobie nie dać.

8 S. Márai, Wyspa, Warszawa 2010, s. 155.

9 Por. L. Witkowski, Ku integralności edukacji i humanistyki II. Postulaty, postacie, pojęcia, próby. Odpowiedź na Księgę jubileuszową, Toruń 2009, s. 105-106, 220-255.

${ }_{10}$ Por. Z. Melosik, Kultura popularna i tożsamość młodzieży. W niewoli władzy $i$ wolności, Kraków 2013, s. 326. 


\section{Zniszczenie przestrzeni myślenia}

To, że uniwersytet jest ważnym dla demokracji miejscem rewitalizacji jej intelektualnych i etycznych zasobów, popadło już niemal całkowicie w zapomnienie (z widocznymi efektami dla życia demokratycznego, np. dla jakości debaty publicznej czy poziomu elit centralnych i lokalnych). Jest tak - pisał Tadeusz Sławek - ,jakby uniwersytet zapomniał o tym, że niezgoda na stan świata jest jego żywiołem”. I tłumaczył:

Nie education, lecz training staje się coraz większą pokusą dla uniwersytetu, a ceną za ulegnięcie tej pokusie jest status pojęcia służby społecznej: całkowite zorientowanie uniwersytetu na kształcenie umiejętności zawodowych oznacza utratę niezależności uczelni na rzecz korporacyjnych struktur kształtujących rynek oraz pozbawienie społeczeństwa siły krytycznej refleksji przyszłych obywateli ${ }^{11}$.

Monokultura wydajności nie respektuje żadnych granic czy różnic. I choć wielu entuzjazmuje się albo uspokaja modernizacją szkolnictwa wyższego jako przejawem postępu, doskonalenia, doganiania (wzorców, jednostek ,flagowych”), trzeba powiedzieć w sposób otwarty: kierunek obecnych reform uniemożliwia kultywowanie tradycji liberal education, a tym samym uderza w jednostkową wolność oraz w jakość sfery publicznej. Atmosfera i organizacyjne wymogi korporacyjnej rywalizacji: system motywacyjny zorientowany na wkład w pomnażanie zysku (przyznawanie funduszy, miejsce w rankingach), grantowe finansowanie badań (z ograniczoną dostępnością, rozbudowaną quasi-biznesową dokumentacją i utylitarnymi kryteriami selekcji), ocena parametryczna oparta na formalnych, a nie merytorycznych wskaźnikach, medialne i urzędnicze rankingi, polityka „oszczędności” uniemożliwiająca pracę z niewielką liczbą studentów (np. dolne limity wielkości grupy, wysokie i nieelastyczne pensum), z góry ustalane przebieg i wyniki kształcenia (w ramach Krajowych Ram Kwalifikacji), co od razu instrumentalizuje cały proces, permanentna sprawozdawczość etc. - to wszystko strategie przystosowujące uniwersytet do dominującej ideologii życia społecznego, a tym samym rujnujące jego status enklawy niezależnego, subwersywnego myślenia. „Uniwersytet nigdy - w żadnym ze swych historycznych

11 T. Sławek, Antygona w świecie korporacji. Rozważania o uniwersytecie i czasach obecnych, Katowice 2002, s. 12, 27. 
modeli - nie był i nie powinien być instytucją o charakterze przedsiębiorstwa" - stwierdza Zofia Zarębianka ${ }^{12}$. Gdyby potraktować poważnie tę przecież oczywistą - prawdę, należałoby wszystkie wymienione przykłady działań i mechanizmów nie tylko skorygować, ale w ogóle zaprzestać myślenia o edukacji wyższej w takich kategoriach. Namysł, wrażliwość i przyjaźń - fundamenty wychowania - nie pojawią się w przestrzeni biznesowego wyścigu. Jeśli wciąż jeszcze mamy z nimi gdzieniegdzie do czynienia, to dzięki osobowościom nadal osadzonym w uniwersyteckiej tradycji, wbrew usilnym staraniom, aby przerobić je w menadżerów informacji.

Wybitny włoski eseista Claudio Magris pisał o zjawisku frustracji Bildung - niezależność myśli może być tak trudna w zderzeniu z codziennością i obrotami losu, że zaczynamy stronić od wysiłku kształcenia: „Skoro wolność i autonomia wydają się niemożliwe, poszukuje się niewoli, aby uwolnić się od nieznośnego ciężaru moralnej odpowiedzialności. Usiłuje się być nikim, rzeczą, przedmiotem, niczym, aby uniknąć niewykonalnego obowiązku bycia podmiotem" "13. Samo istnienie niezależnej przestrzeni jest mało komfortowe dla kogoś, kto od niej ucieka, bo przypomina nieustannie, że niezależność jest możliwa i w dodatku, że jest ludzka powinnością... W tym znaczeniu jest wygodniej, gdy takiej przestrzeni nie ma.

\section{Nieodpowiedzialność}

Reformowanie edukacji wedle wzorca neoliberalnej ekonomii przynosi - czas już mówić o tym otwarcie i głośno - realne i trudne do odwrócenia szkody. Oznacza bowiem odbieranie jednostkom narzędzi emancypacji i skazuje (nazbyt) wielu na los zakładników lokalnego układu sił i doraźnych przesądów. Powtórzmy raz jeszcze: odkrywanie pokładów kultury co do możliwości aranżacji egzystencji nie przychodzi samo z siebie, ale stanowi efekt pomyślnego wpływu wychowawczego. Pozostawianie ludzi - w tym siebie samego - na poziomie pierwotnie dobrze zintegrowanej osobowości, pozbawionej poczucia kulturowego braku, niepokojów sumienia, troski o własne człowieczeństwo i dobro wspólne, za to nieproblematycznie skoncentrowanej na swoich interesach, na tym, co „tu i teraz” i „mnie” jest przydatne, to okradanie ich z życia. Gabriela Marcela nurtował problem kulturo-

12 Z. Zarębianka, Zagrożona tożsamość. O przemianach uniwersytetu w świetle reformy szkolnictwa wyższego, „Kronos” 4 (2013), s. 196.

13 C. Magris, Alfabety, Sejny 2012, s. 114. 
wego uprzywilejowania, które rodzi z jednej strony poczucie wdzięczności, a z drugiej etyczne zobowiązanie: „Ja, który znalazłem się wśród obdarzonych dziedzictwem, jednocześnie mam obowiązek patrzeć na tę sytuację z punktu widzenia otaczających mnie rzesz ludzi pozbawionych dziedzictwa [...]. Moją pierwszą powinnością jest bronić się przed kłamstwem, jakim byłoby stwierdzenie, że ostatecznie ci ludzie także są obdarzeni dziedzictwem" ${ }^{\prime 14}$. W jaki sposób interweniować w świat, aby ci, którzy nie mieli okazji skonfrontować się z najlepszymi wytworami ducha ludzkiego, zyskali taką szansę? To jest pytanie, które nurtowało francuskiego myśliciela, i które odzwierciedla podstawową pedagogiczną odpowiedzialność. Jest coś samolubnego, protekcjonalnego i cynicznego w twierdzeniach tych, którzy liberal education mają za sprawę wąskiej elity, przywilej niepotrzebny większości ludzi i nieprzystający kompletnie do ich sytuacji. Jakby zwykły człowiek nie potrzebował języka, zaplecza obrazów i argumentów, aby samodzielnie radzić sobie z egzystencją; jakby los niewolnika raz przyjętych mniemań, zakładnika aktualnych tendencji, bezwolnego trybiku w maszynerii społecznej był nie tylko prawdopodobny, ale wręcz nieunikniony i słuszny.

Nieodpowiedzialność prorynkowych reform edukacji - wydziedziczonych z tradycji, a przez to nieświadomych, na czym kształcenie naprawdę polega - odbiera jej uczestnikom zapotrzebowanie na znaczenia oraz głos, za pomocą którego można ludzkie doświadczenie wyrazić. Allan Bloom pisał o nękającej nasz czas duchowej entropii i wskazywał, że dzisiejszy fachowiec od komputerów - a nawet niestety, dodajmy, profesor chemii czy pedagogiki - niekoniecznie wie więcej o moralności, polityce, religii, relacjach międzyludzkich od człowieka bez wykształcenia. Wąska specjalistyczna wiedza, pozbawiona zaprawy edukacji liberalnej, skłania do pychy, a dezaktualizująca się szybko branżowa literatura jeszcze bardziej odcina od kultury ogólnej ${ }^{15}$. Również na niższych szczeblach edukacji nauczanie pod testy pozbawia dzieci i młodzież wielu tożsamościowo ważnych i inspirujących opowieści, czyniąc z nich, zarówno w kwestii własnych przeżyć, jak i w sprawach publicznych, praktyczne niemowy, które ani nie mają poważniejszych własnych przemyśleń, ani nie są w stanie ich mieć, bo nie radzą sobie z żadną rozwiniętą wypowiedzią. Zbigniew Kwieciński szacował, że ponad połowa młodych dorosłych nie ma kompetencji do poruszania się w życiu publicznym, bo nie jest zdolna komunikować się za pomocą bardziej

\footnotetext{
${ }^{14}$ G. Marcel, Mądrość i poczucie sacrum, Kraków 2011, s. 57.

15 Por. A. Bloom, dz. cyt., s. 66.
} 
zaawansowanych symboli ${ }^{16}$. Całe pokłady wartościowych odniesień kulturowych stają się dla nieporuszonego wychowawczo człowieka niedostępne. Zbyszko Melosik konstatował, że w odniesieniu do młodzieży mamy dziś do czynienia co najwyżej z „wyskokiem w kulturę wysoką”, raz na jakiś czas, coraz rzadziej ${ }^{17}$.

Długotrwałe przebywanie w środowisku zdominowanym przez kryteria rynkowe nie może nie odbić się na sferze moralnej, chociażby na żywotności idei godności ludzkiej. Pisał o tym Leszek Kołakowski, wskazując, że to, co wciąż uważamy za etycznie oczywiste, i co skłania nas do poniechania pytań w rodzaju Dlaczego nie zabijamy upośledzonych dzieci, skoro ich utrzymanie tyle kosztuje?, wkrótce może się zmienić: „Nasz sposób myślenia został ukształtowany przez wiele dziesięcioleci, kiedy społeczeństwa określały i oceniały same siebie przez pryzmat wydajności i sprawności technicznej; taka mentalność nie tylko tworzy pytania w rodzaju przed chwilą zadanych, ale ma skłonność do odpowiadania na nie za pomocą tych samych kryteriów wydajności i użyteczności" ${ }^{18}$. Z wąskiej perspektywy doraźnych i lokalnych wyobrażeń o zatrudnieniu dostosowywanie edukacji do rynku pracy wydaje się dobrodziejstwem, z którym niemal nikt nie ma potrzeby albo odwagi dyskutować, ale wystarczy spojrzeć na te działania z punktu widzenia niezbędnych narzędzi kształtowania podmiotowości bądź długofalowych skutków etycznych, aby ocenić je jako ewidentnie okaleczające i demoralizujące. Dlatego trzeba pilnie odzyskać uniwersytet ${ }^{19}$ i szkoły dla liberal education, czyli odbudować je jako enklawy refleksyjności, niezbędnej w rozwoju indywidualnym i w demokratycznej sferze publicznej.

\section{Edukacja liberalna a sfera publiczna}

Tadeusz Sławek pisał o przestrzeni społecznościowej: „[...] jest przestrzenią troski, czyli nieobojętności pozwalającej na dostrzeżenie przedmiotów nie tylko w ich funkcji czysto i wyłącznie użytkowej, w której właściwie

${ }^{16}$ Por. Z. Kwieciński, Tropy - ślady - próby. Studia i szkice z pedagogii pogranicza, Poznań-Olsztyn 2000, s. 164.

17 Por. Z. Melosik, dz. cyt., s. 46.

${ }^{18}$ L. Kołakowski, Zabijanie upośledzonych dzieci jako fundamentalny problem filozofii, w: tenże: Niepewność epoki demokracji, Kraków 2014, s. 113.

19 Por. H. A. Giroux, L. Witkowski, Edukacja i sfera publiczna. Idee i doświadczenia pedagogiki radykalnej, Kraków 2010, s. 288-289. 
znikają przed naszym spojrzeniem"20 . A zatem - można powiedzieć - także sfera publiczna, w ramach której społeczność się komunikuje, tworzona jest przez nieobojętnych, którzy są w stanie widzieć więcej, dalej i głębiej niż tylko to, co znajduje się w kręgu bezpośredniej użyteczności czy zatroskania o własny interes. Edukacja liberalna rzuca wyzwanie naszym anomijnym postawom i konwencjonalnej uległości. Przeznaczona jest dla aspirujących do wolności. Dlatego taką trudność sprawia ludziom skoncentrowanym na planach zawodowych i w ogóle wszystkim, którzy dążą do jasno wytyczonych wymiernych celów. Bloom zaobserwował to zjawisko na uniwersytecie: „Z zasady szansę na uzyskanie edukacji liberalnej mają ci studenci, którzy nie wybrali jeszcze konkretnej kariery, a przynajmniej nie traktują uniwersytetu wyłącznie jako szkoły przygotowania zawodowego. Ci, którzy karierę wybrali, studiują z klapkami na oczach [...]"21. Nastawionych na karierę trudniej poruszyć. Jeśli zależy nam na przestrzeni społecznościowej, potrzebujemy nie tyle przygotowania zawodowego, ile wyprowadzającej z obojętności edukacji ważkich lektur, istotnych spotkań, odkrywczych rozmów, niepokojących doznań, troskliwych przemyśleń, inspirujących prób. Szkoła, a później uniwersytet muszą stanowić poligon niebanalnego, poważnego, odpowiedzialnego zabierania głosu w ważnych kwestiach życia duszy i życia społeczności. Jeśli nie tu, to gdzie? Historyk starożytności i filolog klasyczny, Lech Trzcionkowski, trafnie pisał o znaczeniu humanistyki (residuum liberal education) dla jakości życia publicznego:

Niezależnie od tego, co jest przedmiotem naszych poszukiwań, dążymy do zrozumienia myśli i poruszeń wyobraźni, których ślady zostały zapisane w tekstach lub utrwalone w dziełach sztuki. Prowadzimy dyskusje, spieramy się, nie zawsze dochodzimy do konkluzji, lecz zawsze otwieramy drogi dalszych poszukiwań. Czy poziom dyskusji, umiejętność publicznego zabierania głosu i przeprowadzania rozumowania nie jest wartością godną kultywowania? [...] Czy zbywa nam umiejętności pisania zgodnego z regułami gramatyki, logiki i dochodzenia do prawdy? Stawiam zatem tezę, że problemem jest nie tyle zbyt liczny nabór na wydziały humanistyczne, ile systemowe uwarunkowania, które uniemożliwiają kształcenie dobrych humanistów. Ministerstwo, zamiast wspierać pracę na rzecz poprawy warunków nauki, podejmuje działania zniechęcają-

20 T. Sławek, A. Kunce, Z. Kadłubek, Oikologia. Nauka o domu, Katowice 2013, s. 11.

${ }^{21}$ A. Bloom, dz. cyt., s. 443. 
ce młodzież do studiów humanistycznych, co może doprowadzić do głębokiego kryzysu kultury. Ten zaś jest nie mniej groźny od kryzysu gospodarczego ${ }^{22}$.

W znanej koncepcji Jürgen Habermas tłumaczył, że wraz z rozwojem aparatu nowoczesnego państwa w XVII-XVIII wieku nowa warstwa mieszczaństwa (prawnicy, lekarze, duchowni, oficerowie, uczeni, wydawcy, handlowcy, bankierzy, właściciele manufaktur etc.) stworzyła publiczność czytającą. Kryterium przynależności do niej stało się wykształcenie (Bildung). Za pomocą uniwersytetów, oficyn wydawniczych, czasopism, gazet, bibliotek, towarzystw naukowych, oświatowych i czytelniczych, kawiarń stworzona została sieć komunikacji publicznej opartej na regułach taktu, a nie rangi ról społecznych czy bogactwa. Wymiana myśli osób prywatnych dotycząca wspólnych trosk problematyzowała monopolistyczne interpretacje ośrodków władzy. Habermas przyznawał, że tak pojęta sfera publiczna to raczej ideał, ale istotny: „Nie znaczy to, że wraz z kawiarniami, salonami i stowarzyszeniami ta idea publiczności została naprawdę urzeczywistniona; zapewne jednak wraz z nimi zinstytucjonalizowała się jako idea, tym samym zaś zaistniała jako obiektywne roszczenie i o tyle też, nawet jeśli nie została wcielona w życie, to przecież zaczęła wywoływać realne skutki"23. Edukacja liberalna, ożywiając niebłahe pytania oraz udostępniając zasoby kultury, przyczynia się do tego, by roszczenie owocnej społecznej wymiany pozostawało w horyzoncie troski.

\section{Własne zdanie}

Można by uznać - i tak się dzieje często - że mechanizmy demokratyczne, wzmacniane dziś środkami globalnej łączności i masowej komunikacji, zapewniają samoczynnie wymianę opinii i edukacja liberalna nie jest do tego potrzebna. Sfera publiczna istnieje bez niej, i to w skali nigdy wcześniej niespotykanej. Kłopot polega aliści na tym, czy wolno nam uznać samą ekspresję dowolnych sądów za komunikację w sferze publicznej. W potocznym znaczeniu opinia publiczna to po prostu zbiór przekonań wyrażanych w danej społeczności czy też ich dominujący ton, ale w modelu Habermasa nie chodzi o przypadkowe mniemania: „Opinia rozprawiającej publiczności nie

${ }^{22}$ L. Trzcionkowski, Kilka uwag na temat kryzysu humanistyki, „Kronos” 4 (2013), s. $211-212$.

${ }^{23}$ J. Habermas, Strukturalne przeobrażenia sfery publicznej, Warszawa 2007, s. 110. 
jest już zwykłą opinion, wynikiem czystej inclination, lecz skutkiem prywatnego namysłu nad public affairs i publicznej dyskusji nad nimi" ${ }^{24}$. Nie bez powodu jako kryterium niemiecki filozof wymienił Bildung. Aby jakaś myśl weszła w sferę publiczną, musi przejść przez prywatny namyst oraz $d y$ skusję. Nie chodzi o pierwsze lepsze przekonanie, które można żywić arbitralnie i nieodpowiedzialnie, ale o te treści, które przeszły test refleksji i dialogu. Właśnie tradycja liberal education tworzy przestrzeń do wypracowywania własnych myśli, bez niej pozostają nam najczęściej jedynie naskórkowe mniemania.

Wbrew najczęstszym dziś potocznym wyobrażeniom, wcale nie jest łatwo mieć własne zdanie. To jest słaby punkt teorii kształcenia ogólnego Marthy Nussbaum, która nazbyt dużo wagi przywiązuje do potocznie rozumianych opinii studentów, zapominając, ile poczucia braku trzeba mieć w sobie i ile wysiłku za sobą, aby na serio mieć jakąś opinię. Lech Witkowski krytykował amerykańską intelektualistkę: „To jest typowe mylenie zaproszenia do myślenia z zaproszeniem do uporu we własnej bezmyślności, gdzie typowy gest rzekomego »myślenia« polega na stwierdzeniu, że myślę, czyli uznaję. Tymczasem branie odpowiedzialności za własne przekonania wymaga wystawienia ich na próbę w konfrontacji z innymi, w celu wspólnego testowania ich słabości" ${ }^{25}$. I nie chodzi tylko o innych siedzących obok, ale przede wszystkim o wielkie postacie kultury, o tych, którzy mieli czas, siły, doświadczenie, dostęp do zasobów symbolicznych, talent i potrafili zrobić z tego wszystkiego użytek, dzieląc się z nami przenikliwymi przemyśleniami.

W dziele Habermasa przestrzeń publiczna to przestrzeń, w której ci, którzy czują się ,powołani do dojrzałości”, ci, którzy „,czytają”, r e zo n ują w ważkich sprawach, aby zrozumieć siebie samych. Sfera publiczna we właściwym sensie tego słowa - jako ważne obiektywne roszczenie dialogu - to sfera uczestników liberal education i bez tej tradycji najpierw kuleje, później zamiera, wreszcie znika na rzecz manipulowanego spektaklu opinii.

\section{Inteligencja}

Leszek Kołakowski ogłaszał kiedyś nie bez ironii, że polska inteligencja istnieje: „Znaczy to, że istnieje klasa ludzi wykształconych, którzy nie tylko

\footnotetext{
24 Tamże, s. 202.

${ }^{25}$ L. Witkowski, Historie autorytetu, s. 265.
} 
swoje zawodowe umiejętności pielęgnują, ale ponadto interesują się żywo sprawami ogólnymi, sprawami swojego kraju, a także Europy i świata"26. Otóż nie jest wszystko jedno dla jakości życia demokratycznego, jak liczna będzie owa klasa nieobojętnych. A nie będzie liczna, jeśli szkoły i uniwersytety pozostaną kursami przysposobienia zawodowego organizowanymi na modłę przedsiębiorstw, zamiast przestrzeniami służącymi do przeżyć kulturowych. Z kolei instytucje edukacyjne nie staną się warsztatami podmiotowości, jeśli nie stworzy się w nich warunków pracy dla intelektualistów, a nie quasi-biznesmenów rozliczanych za zyski (rankingowe, punktowe, finansowe).

To właśnie zadaniem intelektualistów jest inspirowanie debaty publicznej. W klasycznej wersji nowoczesnej - jak pokazał Zygmunt Bauman - jest to misja inicjowania procesu oświecenia - dostarczania teorii i wciągania w debatę jak najszerszych kręgów społecznych; w wersji ponowoczesnej, a więc $\mathrm{z}$ uwzględnieniem nikłego prawdopodobieństwa konsensu w sprawach światopoglądowych, to rola tłumaczy - udostępniania wytworów kulturowych dla tych, którzy pochodzą z innej wspólnoty interpretacyjnej, kultywowanie swego rodzaju ,sztuki cywilizowanej rozmowy”27. Warto w tym miejscu przywołać jeszcze rozróżnienie Michała Pawła Markowskiego, który pokazywał, że intelektualista to nie jest tradycyjnie rozumiany fachowiec. Nie ogranicza się do żargonu jednej domeny, nie czyta precyzyjnie sprofilowanej literatury, stara się raczej rozregulować język zajmującej go dyscypliny, niż go ujednoznacznić: „Ktoś, kto marzy o przeczytaniu wszystkich książek z jednej dziedziny, nie mieszka w tym samym świecie, co ktoś, kto chce przeczytać najwięcej różnych książek. Pierwszy z nich chce domknąć koło wiedzy, drugi chce je otworzyć" ${ }^{28}$. Chodzi zatem o to, aby stworzyć w szkołach, a zwłaszcza na uniwersytetach, dogodne warunki dla tych, którzy szukają różnych lektur, nie zamykają się w gettach nisko lokalizowanej specjalizacji ${ }^{29}$, zorientowani są na education, a nie na training. Potrzebujemy - od dawna jest to postulat pedagogów radykalnych - nauczycieli transformatywnych intelektualistów. Henry A. Giroux wskazywał, że czas

${ }^{26}$ L. Kołakowski, Henddekalog inteligenta, w: tenże, Niepewność epoki demokracji, Kraków 2014, s. 321.

27 Por. Z. Bauman, Prawodawcy i thumacze.

${ }^{28}$ M. P. Markowski, Polityka wrażliwości. Wprowadzenie do humanistyki, Kraków 2013, s. 27.

29 Por. M. Jaworska-Witkowska, Ku kulturowej koncepcji pedagogiki. Fragmenty i ogarnięcie, Kraków 2009, s. 50. 
skończyć w teorii kształcenia z podziałem na myślenie i wdrażanie, jakby nauczyciel nie był od myślenia, tylko przekazywania treści, realizowania programu. Dziś niestety nauczycieli kształci się na urzędników, ich język to język regulaminów i metodyki. Nie dostarcza się im tymczasem dyskursu do podejmowania rozmowy o życiu publicznym. Potrzebujemy pedagogów jako intelektualistów w służbie zmiany (oczytanych, zaangażowanych, przedkładających swoje przekonania pod dyskusję). To oni - przynajmniej potencjalnie - stanowią awangardę krytycznej publiczności, co jest kluczowe dla procesu upełnomocniania uczniów i kształtowania demokratycznego społeczeństwa. Nauczyciel-intelektualista to nie fachowiec, czyli członek wyspecjalizowanej kasty ekspertów, tylko ktoś autokrytyczny, kto łączy wiedzę z własnym i społecznym rozwojem, kto nie może być zadowolony $\mathrm{z}$ tkwienia $\mathrm{w}$ jednym dyskursie (pedagog krytyczny musi być zdolny do przekraczania granic, przemieszczania analiz) ${ }^{30}$.

Tylko w jaki sposób znaleźć zastępy takich nauczycieli i wykładowców? Nie będzie ich bez długotrwałego oddziaływania edukacji liberalnej (koło się zamyka!). Nawet jednostkowi intelektualiści będą pojawiać się coraz rzadziej, bo zabraknie środowiska, w którym ich działanie będzie zrozumiałe. Mihail Sebastian, rumuński powieściopisarz i dramaturg żydowskiego pochodzenia, odnotował w Dzienniku wykład z 1943 roku, w którym prelegent wbrew własnym i większości audytorium nazistowskim sympatiom i to w sercu kraju, który walczył u boku Hitlera, sławił Anglię. Sebastian w pierwszej chwili pomyślał, że to szaleństwo, ale wkrótce odkrył, iż sprawy wyglądają inaczej: „Nie ma to żadnego znaczenia i nie będzie miało żadnych następstw. Oto legionista sławi ducha Anglii w obliczu sali wypełnionej studentami, którzy też są albo rzeczywistymi, albo potencjalnymi legionistami i których słowa wykładowcy nic a nic nie obchodzą. Nie odczuwają żadnej potrzeby, aby się nad nimi zastanowić, aby się im przeciwstawić"31. Jeśli brakuje elementarnego zainteresowania sprawami ludzkimi czy publiczny$m i$, jeśli nie ma środowiska zdolnego do odbioru bardziej zaawansowanych konstelacji znaczeń - a nie ma wszędzie, gdzie w sposób długotrwały ludzie poddawani są utylitarnemu treningowi - wyspowy intelektualista nie ma warunków do pracy. Nawet najbardziej twórczy nauczyciel i najprzenikliwszy profesor niczego nie wskórają, jeżeli nikt wokół - w pogoni za rynkową adekwatnością - nie będzie miał potrzeby zastanowić się nad tym, co proponują, albo się temu rozumnie przeciwstawić. Uważam za mit

\footnotetext{
${ }^{30}$ Por. H. A. Giroux, L. Witkowski, dz. cyt.

${ }^{31}$ M. Sebastian, Dziennik 1935-1944, Sejny 2006, s. 849.
} 
przekonanie, że edukacja liberalna może przetrwać w realnym kształcie jako domena wąskiej elity. Trujące opary administracyjnie wspieranego indyferentyzmu zabiły liberal education dla zbyt wielu.

\section{Ranga sprawy}

Nie ma żadnych powodów do optymizmu. Niezwykle ważna - łącząca się z ideami paideia, humanitas, Bildung - tradycja liberal education została niemal całkowicie wyparta ze szkół i uniwersytetów na rzecz prymitywnych testowych szkoleń i kursów przysposobienia rynkowego. Nie o to chodzi, oczywiście, że przygotowanie zawodowe nie ma racji bytu. Ma i nikt się o to nie spiera. Rzecz tylko w proporcjach, w złożoności ujęcia i w świadomości tego, kim jest (może być) człowiek poza rolą zawodową. Dziś z marginesu/dodatku kształcenia uczyniono hegemoniczną perspektywę, która większości jawi się już jako jedyna. Aliści koszty ludzkie są ogromne. Duchowa wolność i poważna myśl o sprawach publicznych utraciły przestrzeń, w której mogły się kształtować. Jednostka została pozbawiona większości szans na wydostanie się z wirów redukcji kulturowej, czyniących z niej nieświadomego zakładnika socjalizacji, nieprzeczuwającego nawet, że istnieją wielkie zagadki i alternatywne sposoby życia, a demokracja utraciła mechanizm równoważenia procesów banalizacji i entropii duchowej oraz etyczne oblicze - troskę o kulturowo wydziedziczonych. Jeśli popatrzymy z tej perspektywy, stanie się jasne, że w obronie liberal education nie chodzi o restytucję przebrzmiałej tradycji, utopijny sentyment za rzekomo szlachetnymi czasami, których przywoływanie dziś jest daremne, ale o kształt współczesności. Edukacja liberalna to ultranowoczesna kwestia tego, w jakim świecie chcemy żyć. Ja wolałbym rzeczywistość ludzi wzruszonych, przejętych, zachwianych $\mathrm{w}$ wierze $\mathrm{w}$ dzień i $\mathrm{moc}^{32}$, dlatego upominam się o tradycję i styl liberal education. W ostatecznym rachunku stawką jest wolność.

\section{Space of the Agitated: Liberal Education and the Public Sphere (Reanimation Voice) (Summary)}

The liberal education is ultimately about a freedom. It consists in considering the existential questions and revaluating initial social expectations. It is, in fact,

${ }^{32}$ Por. J. Patočka, Eseje heretyckie z filozofii dziejów, Warszawa 1998, s. 163-188. 
a concern for humanity. Schools, and especially, universities, are the privileged places of such care, and they are important for individual development and the quality of the public sphere. Today, the tradition of liberal education has been destroyed. The climate of consumerism and irresponsible market education reforms hit the essence of education and condemn pupils, students and teachers to fate of a hostage of the environment and moment. However, one cannot give up on the society of empathetic people, therefore, the liberal education must be reanimated.

Keywords: liberal education; public sphere; emancipation; harmful reforms; university; teachers as intellectuals.

\section{Przestrzeń wzruszonych. Edukacja liberalna a sfera publiczna (glos reanimacyjny) (Streszczenie)}

W kształceniu ogólnym ostatecznie chodzi o wolność. Polega ono na rozważaniu egzystencjalnych pytań i przewartościowaniu wstępnych społecznych nastawień. To w istocie troska o człowieczeństwo. Szkoły, a zwłaszcza uniwersytety, stanowią uprzywilejowane miejsca takiej troski i są ważne dla indywidualnego rozwoju oraz dla jakości sfery publicznej. Współcześnie tradycja edukacji liberalnej została zniszczona. Klimat konsumeryzmu i nieodpowiedzialne rynkowe reformy edukacji uderzają w istotę wychowania i skazują uczniów, studentów i nauczycieli na los zakładników otoczenia i chwili. Nie wolno jednak zrezygnować ze społeczeństwa ludzi nieobojętnych, dlatego trzeba reanimować edukację liberalną.

Słowa kluczowe: kształcenie ogólne; sfera publiczna; emancypacja; szkodliwe reformy; uniwersytet; nauczyciele jako intelektualiści. 
